\title{
Impact of water temperature of chimarrão on phenolic compounds extraction
}

\author{
Tayse Ferreira Ferreira da SILVEIRA ${ }^{1}$, Adriana Dillenburg MEINHART ${ }^{1,2 *} \mathbb{( D}$, Thaís Cristina Lima de SOUZA ${ }^{1}$, \\ Elenice Carla Emídio CUNHA ${ }^{1}$, Maria Rosa de MORAES ${ }^{1}$, Alexandre LORINI², José TEIXEIRA FILHO ${ }^{3}$, \\ Helena Teixeira GODOY ${ }^{1}$
}

\begin{abstract}
This study evaluated the effect of water temperature $\left(65^{\circ} \mathrm{C}, 75^{\circ} \mathrm{C}, 85^{\circ} \mathrm{C}, 95^{\circ} \mathrm{C}\right)$ on the concentration of caffeic acid, 5-caffeoylquinic acid, 3,4-dicaffeoylquinic acid, 3,5-dicaffeoylquinic acid, 4,5-dicaffeoylquinc acid and rutin in chimarrão aqueous extracts prepared from two commercial types of yerba mate: traditional and coarse ground. The chimarrão preparation simulated the homemade process. Regardless of the temperature, aqueous extracts from the coarse ground had $60 \%$ more phenolic compounds than the traditional ones. In the extracts of coarse ground yerba mate the temperature of $95{ }^{\circ} \mathrm{C}$ favored the extraction of the compounds in relation to the other temperatures. For the traditional yerba mate extracts there was no difference regarding the temperature. The chlorogenic acids content in the chimarrão extracts is significantly higher than in other foods and beverages and represent an excellent contribution for chlorogenic acids intake.
\end{abstract}

Keywords: chlorogenic acids; Ilex paraguariensis; infusion; yerba mate.

Practical Application: Chimarrão consumers will be able to choose the best temperature and type of herb for chimarrão preparation. They will be able to estimate their daily intake of phenolic compounds from the beverage they prepare.

\section{Introduction}

Yerba mate (Ilex paraguariensis), originated from subtropical South America, is widely used in infusions preparation, such as chimarrão, tererê and mate tea, which are widely appreciated because of their sensorial and stimulant properties (Heck \& De Mejia, 2007). Among them, chimarrão is a partial infusion prepared by vertically placing the yerba mate into a container called cuia and pouring hot water in the gap between the herb and the sidewall of the cuia. The beverage is ingested by suction through a metal artifact called bomba (Gebara et al., 2017). Successive additions of water are made to the cuia so that fresh infusions are prepared from the same herb until the loss of flavor is noticed by the consumer (Meinhart et al., 2010). The market provides yerba mate with different characteristics regarding the origin, composition of stems and leaves, particle size and the addition of other ingredients to the yerba mate. The traditional and coarse ground yerba are the most consumed types of yerba mate for chimarrão preparation. Both are made from mixing native and cultivated yerba mate, however, the coarse ground has a larger particle size (about 200 mesh) in comparison with the traditional one (about 500 mesh) (Bizzotto et al., 2012).

The plant has been pointed out as a source of phenolic compounds, particularly the derivative esters of caffeic acid and quinic acid and their mono and dicaffeoylquinic acid isomers, such as 5-caffeoylquinic acid, 3,4-dicaffeoylquinic acid, 3,5- dicaffeoylquinic acid, 4,5- dicaffeoylquinic acid. Also, yerba mate has a high content of flavonoids, being rutin the predominant flavonoid compound in the plant (Bizzotto et al., 2012).

The aqueous extracts of yerba mate showed high antioxidant capacity, anti-inflammatory, anti-mutagenic, anti-proliferative, cardioprotective and anti-obesity properties (Boaventura et al., 2015; Miranda et al., 2008; Pimentel et al., 2013; Wan et al., 2012). The chlorogenic acids present in high amount in the yerba mate have been associated, in in vitro and in vivo studies, to several beneficial effects on health, including the ability to modify the glucose metabolism, playing a role in its absorption, oxidative stress attenuation, protection against inflammation in diabetic nephropathy (Peng et al., 2015; Wang et al., 2008) and sensorineural hearing impairment caused by diabetes (Hong et al., 2017), liver protection against the formation of fibrosis induced by $\mathrm{CCl}_{4}$ or caused by cholestasis (Shi et al., 2016; Wu et al., 2015), inhibiting of the replication of the hepatitis B virus (Wang et al., 2009), reduction of total cholesterol and LDL (low density lipoprotein) and increase levels of HDL (high-density lipoprotein) (Wan et al., 2013), in addition to inhibiting the proliferation of tumor cells in the stomach, colon, (Matsunaga et al., 2002; Shao et al., 2015) and liver (Siswanto et al., 2017; Yan et al., 2017). 
Given the importance of these compounds and the high amount present in yerba mate, it is extremely relevant to study the preparation conditions of the chimarrão, in order to enable the maximum extraction of the bioactive compounds for the beverage ingested by consumers. It has been shown that compounds released from the plants may be affected by several parameters, being the temperature of the water used in the infusion preparation a critical parameter (Horžić et al., 2009; Kelebek, 2016). Thus, water temperature increase may favor the transference of the compounds by increasing their solubility, or may promote the degradation of the compounds and decrease their content in the aqueous extracts ingested by the consumer (Horžić et al., 2009; Jeon et al., 2017; Komes et al., 2010). Studies have already been reported evidencing the importance of temperature in the extraction of bioactive compounds during the preparation of infusions (Jeon et al., 2017; Pérez-Burillo et al., 2018), but no studies were found evaluating the effect of this parameter on the concentration of phenolic compounds in the infusions obtained during the consumption of chimarrão.

Therefore, this work aimed to study the effect of temperature of the water used for chimarrão preparation on the migration of caffeic acid, 5-caffeoylquinic acid (5-CQA), 3,4-dicaffeoylquinic acid (3,4-DQA), 3,5-dicaffeoylquinic acid (3,5-DQA), 4,5-dicaffeoylquinic acid (4,5-DQA) and rutin from the plant to the aqueous extracts ingested by the consumer. Two commercial yerba mate types were used in this study: traditional and coarse ground.

\section{Material and methods}

\subsection{Samples}

Chromatography-grade methanol (Merck, Germany) and analytical-grade formic acid (Ecibra, Brazil) were used. Water was purified using a Milli- ${ }^{\circledR}$ (Millipore) system. The phenolic compound standards (caffeic acid, 5-CQA, 3,4-DQA, 3,5-DQA, 4,5-DQA, and rutin) were obtained from Biopurify Phytochemicals Ltd. (Chengdu, China). Standard stock solutions were prepared in methanol at a concentration of $1 \mathrm{mg} \mathrm{mL}^{-1}$ and kept at $-18^{\circ} \mathrm{C}$ for 1 month at most. Organic and aqueous solutions were filtered using polyvinylidene (PVDF) and cellulose membranes, respectively, both with a porosity of $0.22 \mu \mathrm{m}$ (Millipore).

Yerba mate samples were courteously provided by the Ervateria Vier, located in Rio Grande do Sul, Brazil. The chimarrão samples were named as traditional and coarse ground. The herbs were produced with a mixture of leaves and stems (84:26, respectively) of native plants $(70 \%)$ and cultivated plants $(30 \%)$. The plants used in the production of the traditional and coarse ground herbs are originated from the same place. The only difference between them was the size of the mill, being 200 mesh for the coarse ground and 500 mesh for the traditional. Ten kilograms of each type of yerba mate were provided in the packages commonly used for commercialization $(1000 \mathrm{~g})$. The content of the respective yerba mate packs was mixed and homogenized before being used for the preparation of chimarrão infusions.

\subsection{Aqueous extracts preparation}

The aqueous extracts of yerba mate were obtained according to Da Silveira et al. (2017). Briefly, $85 \mathrm{~g}$ of yerba mate were vertically arranged in an average-sized cuia (with total volume of $350 \mathrm{ml}$ of water or about $170 \mathrm{~g}$ of yerba mate). The "pump" was positioned and fixated in the remaining space of the cuia and coupled to a vacuum system. Next, the cuia was filled with hot water at $65^{\circ} \mathrm{C}$ and kept in a partial infusion for 30 seconds, after which the resulting yerba mate aqueous extract was suctioned with the aid of the vacuum system. These steps were repeated 30 times, which represented the number of successive additions of water usually made by consumers (Meinhart et al., 2010). The extract was collected, the volume registered, filtered in common filter paper, diluted with water to fit the standard curve, filtered using polyvinylidene (PVDF) membranes with $0.22 \mu \mathrm{m}$ (Millipore) porosity and injected into the HPLC. The same process was repeated using hot water at temperatures of $75^{\circ} \mathrm{C}$, $85^{\circ} \mathrm{C}$ and $95^{\circ} \mathrm{C}$. The experiment was carried out in triplicate for each temperature.

\subsection{Methanolic extraction of phenolic compounds from yerba mate}

An exhaustive extraction of the phenolic compounds was performed using methanol, according to Meinhart et al. (Meinhart et al., 2010). Two grams of ground yerba mate were mixed with $10 \mathrm{~mL}$ of methanol for 3 hours, followed by centrifugation for $10 \mathrm{~min}$. at $3500 \mathrm{~g}$. The upper phase was collected and the solid residue was subjected to a new extraction with $10 \mathrm{ml}$ of methanol for 1 hour. The extracts were combined, transferred to a volumetric flask $(25 \mathrm{~mL})$, filtered and injected into the HPLC.

The content of phenolic compounds measured in the methanolic extracts (equivalent to 100\%) was compared with the amount of these compounds in the aqueous extracts. Thus, it was possible to estimate the percentage of phenolic compounds migrating from the matrix to the aqueous extract during the infusion time ( 30 seconds) and along the successive extractions (30 times).

\subsection{Chromatographic conditions}

The chromatographic method optimized and validated, according to International Union of Pure and Applied Chemistry (Harmonized guidelines for single-laboratory validation of methods of analysis (IUPAC Technical Report), 2002), by Da Silveira et al. (Da Silveira et al., 2016) was applied for the quantification of phenolic compounds in both aqueous and methanol extracts of yerba mate. The separation was performed using a HPLC system model 1100 (Agilent Technologies, Santa Clara, CA, USA), coupled with a diode array detector and reverse phase column C18 ACE (Switzerland) that was $100 \mathrm{~mm}$ in length and $4.6 \mathrm{~mm}$ in diameter with $3 \mu \mathrm{m}$ particle size. The mobile phase consisted of methanol and an aqueous solution of formic acid $0.1 \%(\mathrm{v} / \mathrm{v})$. The linear gradient started with $13.6 \%$ of methanol and achieved $40 \%$ in 39.4 minutes. The detection was recorded at $325 \mathrm{~nm}$. HP-Chemstation software was used for data analysis. 


\subsection{Statistical treatment}

The results obtained were compared by analysis of variance (ANOVA) and Tukey's test in Statistica 6.0 from StatSoft (Tulsa, USA). The samples were considered to be significantly different when $p<0.05$.

\section{Results and discussion}

Many factors can alter the amount of bioactive compounds in yerba mate aqueous extracts, such as geographical region, growing and processing conditions (Da Silveira et al., 2016; Isolabella et al., 2010; Thompson et al. 2002). Moreover, factors related to beverage preparation can also affect the concentration of substances in the extracts, including time, the temperature of infusion, the mass ratio of herbs/water volume and particle size (Gebara et al., 2017; Da Silveira et al., 2016). In a previous study (Da Silveira et al., 2017), we demonstrated that the type of yerba mate (different particle size and leaf and stem composition) used to prepare chimarrão affects the extraction of chlorogenic acids and rutin. The present approach provides complementary data by demonstrating that in addition to this factor, water temperature may play an important role in the amount of phenolic compounds in aqueous extracts of yerba mate.

Table 1 shows the content of rutin and chlorogenic acids in the methanolic extracts relative to $85 \mathrm{~g}$ of yerba mate (amount used in the experiments). The results indicated the predominance of 3,5-DQA (1750.2 $\mathrm{mg}$ for traditional and $1704.4 \mathrm{mg}$ for coarse ground) and 5-CQA (1379.5 mg for traditional and $1360.8 \mathrm{mg}$ for coarse ground), which is in agreement with the previously mentioned literature (Bizzotto et al., 2012; Marques \& Farah, 2009). Table 1 also shows the percentage of the compounds that was transferred to the 30 aqueous extracts of chimarrão, in the different temperatures studied. It can be observed that the extraction rate varied between $4.0 \%$ (for rutin at $65^{\circ} \mathrm{C}$ with traditional yerba mate) and $28.3 \%$ (for $3,4-\mathrm{DQA}$ at $95{ }^{\circ} \mathrm{C}$ with coarse ground yerba mate).

With respect to the type of yerba mate, it can be observed that in all studied temperatures and for all the investigated compounds, the extraction was greater (2.4 times) when the chimarrão was prepared with coarse ground yerba mate. This can be observed in the sum of all extracted compounds, considering the average extracted in different temperatures, with the extracts prepared with coarse ground yerba mate giving $17.5 \%$ of the content present in the plant, whereas in the extracts prepared with traditional yerba mate, transference of only $7.3 \%$ was observed.

The particle size has been reported as the factor with the greatest impact in the extraction of phenolic compounds from yerba mate (Gebara et al., 2017). Meinhart et al. (Meinhart et al., 2010), studying aqueous extracts of coarse ground and traditional yerba mate, reported similar behavior for the extraction of methylxanthines and total phenolic compounds, and suggested that the higher content found in the coarse ground extracts may be linked to the higher penetration of water as a consequence of the superior particle size. Similar findings were also reported by Gebara et al. (Gebara et al., 2017) when comparing the extraction of chlorogenic acids from chimarrão (60 mesh) and tererê (30 mesh), with the higher extraction observed for larger particles. Small particles (traditional) form a barrier that hinders

Table 1. Content of the compounds present in the yerba mate and percentage extracted for the beverages of chimarrão in different temperatures.

\begin{tabular}{|c|c|c|c|c|c|c|}
\hline \multicolumn{7}{|c|}{ Coarse ground yerba mate } \\
\hline \multirow{2}{*}{ Compound } & \multirow{2}{*}{ Content in yerba mate $\left(\mathrm{mg} 85 \mathrm{~g}^{-1}\right)$} & \multicolumn{5}{|c|}{ \% Extracted with 30 extracts } \\
\hline & & $65^{\circ} \mathrm{C}$ & $75^{\circ} \mathrm{C}$ & $85^{\circ} \mathrm{C}$ & $95^{\circ} \mathrm{C}$ & Average \\
\hline 5-CQA & $1360.8^{a}$ & $20.0^{\mathrm{a}}$ & $14.8^{\mathrm{a}}$ & $18.0^{\mathrm{a}}$ & $28.1^{\mathrm{a}}$ & $20.2^{a}$ \\
\hline 3,4-DQA & $251.6^{\mathrm{a}}$ & $18.2^{\mathrm{a}}$ & $14.9^{\mathrm{a}}$ & $19.1^{\mathrm{a}}$ & $28.3^{\mathrm{a}}$ & $20.1^{\mathrm{a}}$ \\
\hline 4,5-DQA & $454.7^{\mathrm{a}}$ & $17.9^{\mathrm{a}}$ & $14.9^{\mathrm{a}}$ & $17.9^{\mathrm{a}}$ & $27.3^{\mathrm{a}}$ & $19.5^{\mathrm{a}}$ \\
\hline Rutin & $397.8^{\text {a }}$ & $11.8^{\mathrm{a}}$ & $9.6^{\mathrm{a}}$ & $11.9^{\mathrm{a}}$ & $17.6^{\mathrm{a}}$ & $12.8^{\mathrm{a}}$ \\
\hline \multicolumn{2}{|c|}{ Average \% extracted } & 16.2 & 13.2 & 16.2 & 24.5 & 17.5 \\
\hline \multicolumn{7}{|c|}{ Traditional yerba mate } \\
\hline 5-CQA & $1379.5^{\mathrm{a}}$ & $6.8^{b}$ & $9.8^{\mathrm{b}}$ & $7.2^{\mathrm{b}}$ & $8.0^{\mathrm{b}}$ & $7.9^{\mathrm{b}}$ \\
\hline 3,4-DQA & $256.7^{\text {a }}$ & $6.4^{\mathrm{b}}$ & $9.1^{\mathrm{b}}$ & $7.6^{\mathrm{b}}$ & $10.6^{\mathrm{b}}$ & $8.4^{\mathrm{b}}$ \\
\hline 3,5-DQA & $1750.17^{\text {a }}$ & $5.1^{\mathrm{b}}$ & $6.7^{\mathrm{b}}$ & $5.3^{\mathrm{b}}$ & $5.0^{\mathrm{b}}$ & $5.5^{\mathrm{b}}$ \\
\hline 4,5-DQA & $492.4^{\mathrm{a}}$ & $6.5^{b}$ & $9.2^{b}$ & $7.5^{\mathrm{b}}$ & $8.1^{\mathrm{b}}$ & $7.8^{b}$ \\
\hline Rutin & $382.9^{\mathrm{a}}$ & $4.0^{\mathrm{b}}$ & $6.0^{\mathrm{b}}$ & $4.3^{\mathrm{b}}$ & $3.9^{\mathrm{b}}$ & $4.5^{\mathrm{b}}$ \\
\hline \multicolumn{2}{|c|}{ Média \% extracted } & 5.9 & 8.5 & 6.7 & 8.1 & 7.3 \\
\hline
\end{tabular}


the passage of water and reduces the extraction capacity, while larger particles (coarse ground) provide greater contact and consequently greater extractive capacity. This hypothesis is supported by the average volumes of aqueous extracts collected in each of the 30 successive extractions, which were $25 \%$ higher in traditional $(95.0 \pm 6.7 \mathrm{~mL})$ than in coarse ground $(75.0 \pm 5.7 \mathrm{~mL})$, showing that larger amounts of water have permeated the coarse ground yerba mate type.

When investigating the effect caused by the temperature difference, in the coarse ground yerba mate the highest extraction percentage for all the compounds occurred with water at $95^{\circ} \mathrm{C}$, allowing the average extraction of $24.5 \%$ of the compounds. No significant difference was observed in the extraction between the temperatures of $65^{\circ} \mathrm{C}, 75^{\circ} \mathrm{C}$, and $85^{\circ} \mathrm{C}$, which correspond to the average values of $16.2 \%, 13.2 \%$ and $16.2 \%$, respectively. However, this extraction percentage is still higher than the extracts obtained from the traditional yerba mate, which had values oscillating between $5.9 \%$ and $8.1 \%$. Regarding the traditional yerba mate, the results indicated that the increase in temperature did not affect significantly $(p>0.05)$ the transfer of the phenolic compounds studied to the aqueous extracts of chimarrão. The different behavior between the different types of herbs on increasing the temperature may be related to the effect of the greater compaction of the traditional yerba mate because of its smaller particle size, as previously mentioned. It is possible that the greater compaction has hindered the contact of the leaves with the infusion water, reducing the extractability, and, in turn, the effect of the infusion temperature may have been suppressed.

Figure 1 shows the content of the compounds accumulated in the aqueous extracts throughout the extractions, simulating the concentration of the phenolic compounds ingested by consumers. Confirming the results observed, it is apparent that the extracts prepared with coarse ground yerba mate had a higher average amount of phenolic compounds than the ones obtained with traditional yerba mate. In addition, the extracts prepared with coarse ground and water at $95^{\circ} \mathrm{C}$ stood out from the others, showing higher amounts $(\mathrm{p}<0.05)$ of all phenolic compounds investigated, which could be attributed to the higher solubility of these in boiling or near boiling water temperature (De Maria et al., 1998). Therefore, our results suggest that the preparation of chimarrão with coarse-ground yerba mate and infusion at $95^{\circ} \mathrm{C}$ is an alternative of a better contribution of phenolic compounds compared with the traditional one. However, in spite of this result, the other temperatures also provided high amounts of these compounds.

Gebara et al. (Gebara et al., 2017) estimated an average daily intake of 648-2160 mL/person of chimarrão, which could provide between 512.5-1708.0 mg of chlorogenic acids (mono and dicaffeoylquinic acids). Our results are in accordance with these ranges of volume (30 extracts) and phenolic compounds extraction. Yerba mate is a main source of chlorogenic acids for the diet, along with coffee. One coffee serving corresponding to $200 \mathrm{~mL}$ provides between $44 \mathrm{mg}$ and $241 \mathrm{mg}$ of 5-CQA, 0.84 and $13.67 \mathrm{mg}$ of 3,4-DQA, 0.512 and $9.374 \mathrm{mg}$ of 3,5-DQA, and 0.704 and $12.356 \mathrm{mg}$ of 4.5-DQA (Jeon et al., 2017). According to Table 2, with the exception of 5-CQA, these amounts are obtained with the consumption of 10 extracts and are highly superior if one considers the consumption of 30 extracts (which comprises the average volume/person of chimarrão), regardless of the herb or the infusion temperature chosen. In this regard, chimarrão extracts can be highlighted as a remarkable source of dicaffeoylquinic compounds. For example, Marques and Farah (Marques \& Farah, 2009) studied 14 medicinal plant infusions and found that even though 5-CQA was present in every species, dicaffeoylquinic acids were detectable only in Baccharis genistelloides ("carqueja"), seeds of Pimpinella anisum (anise), and flowers of Achyrocline satureioides ("macelle"), but in amounts still greatly lower than those in chimarrão extracts. In another study, Meinhart et al. (2018) investigated the content of chlorogenic acids in 89 plant infusions, and demonstrated that 5-CQA was the most commonly found compound from this family $(72 \%$ of the samples) in ranges between $0.002 \mathrm{mg}^{\circ} 100 \mathrm{~mL}^{-1}$ and $6.349 \mathrm{mg} .100 \mathrm{~mL}^{-1}$. The content of dicaffeoylquinic acids found was from traces of 4,5-DQA until $13.334 \mathrm{mg} .100 \mathrm{~mL}^{-1}$ (3,5-DQA), demonstrating that yerba mate infusions such as chimarrão could provide greatly higher amounts of these compounds.

Chimarrão extracts have also been pointed out as a good source of the flavonoid rutin and according to Bizzotto et al. (Bizzotto et al., 2012), yerba mate is one of the richest sources of this compound in nature. The levels of rutin in chimarrão extracts found in this study are in accordance with those from Colpo et al. (2016), who found $19 \mathrm{mg}$ and $12.85 \mathrm{mg}$ of rutin in $1000 \mathrm{~mL}$ of chimarrão extracts (approximately 10 extracts) from coarse ground and traditional yerba mate, respectively, prepared at $75^{\circ} \mathrm{C}$. Jeszka-Skowron et al. (2015) reported that $200 \mathrm{~mL}$ of white, black and green tea (Camelia sinesis), which are important sources of flavonoids in the diet, supplied on average $0.527 \mathrm{mg}$, $4.4 \mathrm{mg}$ and $5 \mathrm{mg}$, respectively, of rutin. Therefore, the content found in 10 extracts of traditional or coarse ground yerba mate, at any studied temperature, provides between 10 and 20 times more rutin than tea.

The beneficial biological effects of the intake of CGAs have already been reported in several studies. For example, according to Wan and colleagues (Wan et al., 2013), the intake of 1 to $10 \mathrm{mg}$ of chlorogenic acids per gram of body weight per day has beneficial effects on lipid metabolism leading to a significant reduction of total cholesterol, LDL and HDL. Considering the data in Table 2, a consumer who ingests, per day, only the first 10 extracts of aqueous chimarrão extract, prepared with traditional yerba mate and water at $65^{\circ} \mathrm{C}$ (condition with the lowest average content extracted), has the contribution of $159 \mathrm{mg}$ daily (considering only chlorogenic acids) which corresponds to $2.27 \mathrm{mg}$ per $\mathrm{kg}$ per day in a $70 \mathrm{~kg}$ individual. On the other hand, the consumer who ingests 30 extracts has the intake of $3.30 \mathrm{mg}$ per kg per day. The consumer who ingests the first 10 extracts of chimarrão, with coarse-ground yerba mate and water at $95^{\circ} \mathrm{C}$, has a daily intake of $6.74 \mathrm{mg}$ per $\mathrm{kg}$ per day, or $12.7 \mathrm{mg}$ per $\mathrm{kg}$ per day if the ingestion is of 30 extracts. As seen in Figure 1, the first extracts are the most relevant and represent a large part of the extraction. Consumers who ingest a lower amount of the beverage, such as the first 5 extracts, also have a satisfactory intake. If the first 5 extracts prepared with traditional yerba mate and water at $65^{\circ} \mathrm{C}$ are ingested, the intake is $1.76 \mathrm{mg}$ per body weight per day. If the ingestion is of extracts from coarse 

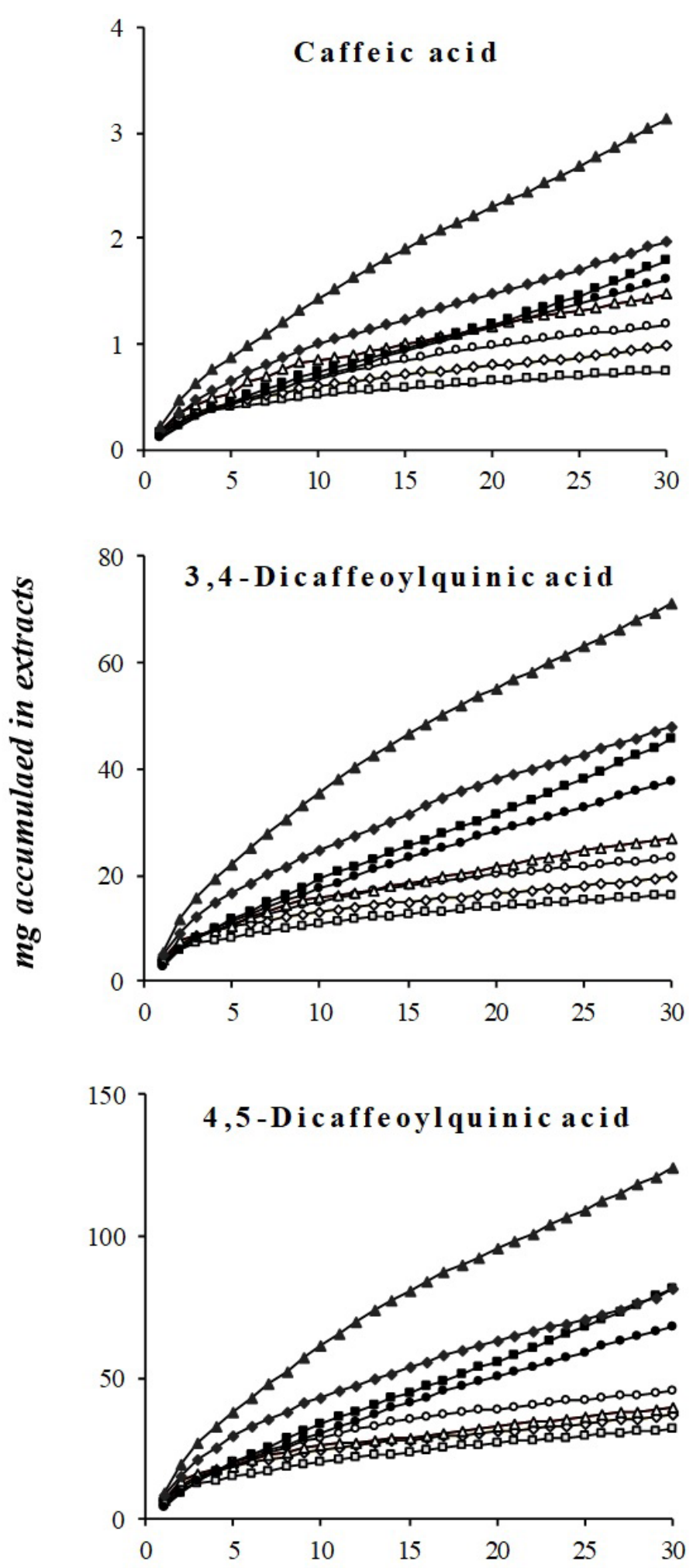
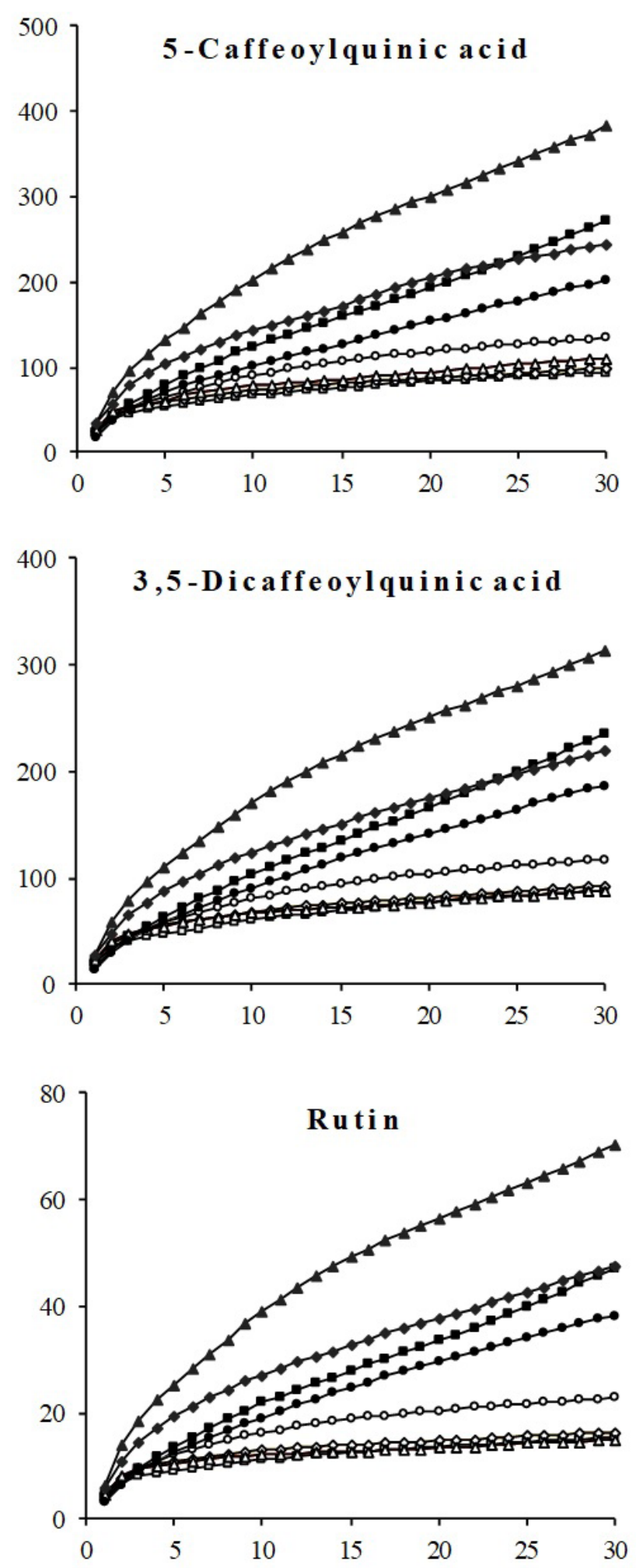

Number of exracs

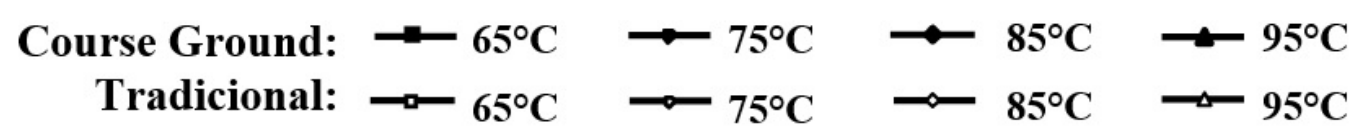

Figure 1. Content of bioactive compounds extracted cumulatively during the extraction of the 30 extracts of chimarrão, using different temperatures, in course ground and traditional yerba mate 
Silveira et al.

Table 2. Sum of the content of phenolic compounds in the first 10 chimarão extracts (mg) and in 30 chimarrão extracts (mg).

\begin{tabular}{|c|c|c|c|c|c|c|c|c|c|c|}
\hline \multicolumn{11}{|c|}{ Coarse ground yerba mate } \\
\hline \multirow{2}{*}{ Compound } & \multicolumn{5}{|c|}{ mg in 10 chimarrão extracts } & \multicolumn{5}{|c|}{ mg in 30 chimarrão extracts } \\
\hline & $65^{\circ} \mathrm{C}$ & $75^{\circ} \mathrm{C}$ & $85^{\circ} \mathrm{C}$ & $95^{\circ} \mathrm{C}$ & Average & $65^{\circ} \mathrm{C}$ & $75^{\circ} \mathrm{C}$ & $85^{\circ} \mathrm{C}$ & $95^{\circ} \mathrm{C}$ & Average \\
\hline 5-CQA & 124.7 & 101.2 & 142.6 & 203.4 & 143.0 & 271.6 & 202.0 & 244.5 & 382.4 & 271.6 \\
\hline 3,4-DQA & 19.2 & 17.5 & 24.6 & 35.6 & 24.2 & 45.7 & 37.5 & 48.0 & 71.3 & 45.7 \\
\hline 4,5-DQA & 33.6 & 30.8 & 43.1 & 61.9 & 42.3 & 81.4 & 67.9 & 81.3 & 124.1 & 81.4 \\
\hline Rutin & 21.9 & 19.1 & 27.2 & 39.0 & 26.8 & 47.1 & 38.3 & 47.5 & 70.2 & 47.1 \\
\hline Total phenolics & 303.1 & 259.7 & 363.0 & 512.5 & 359.6 & 683.7 & 534.3 & 643.7 & 964.3 & 683.7 \\
\hline \multicolumn{11}{|c|}{ Traditional yerba mate } \\
\hline 5-CQA & 67.1 & 90.1 & 72.9 & 78.9 & 77.2 & 94.2 & 134.5 & 98.8 & 110.7 & 109.6 \\
\hline 3.4-DQA & 10.9 & 15.0 & 13.1 & 15.7 & 13.7 & 16.3 & 23.2 & 19.6 & 27.2 & 21.6 \\
\hline 3.5-DQA & 60.7 & 81.0 & 68.3 & 67.3 & 69.3 & 88.6 & 117.9 & 92.4 & 88.1 & 96.7 \\
\hline 4.5-DQA & 20.2 & 29.0 & 24.5 & 26.1 & 25.0 & 32.2 & 45.2 & 36.9 & 39.8 & 38.5 \\
\hline Rutin & 11.2 & 16.2 & 13.0 & 12.1 & 13.1 & 15.4 & 22.8 & 16.4 & 15.0 & 17.4 \\
\hline Total phenolics & 170.7 & 232.1 & 192.4 & 200.9 & 199.0 & 247.4 & 344.9 & 265.1 & 282.2 & 284.9 \\
\hline
\end{tabular}

ground yerba mate with water at $95{ }^{\circ} \mathrm{C}$, the average value is $4.3 \mathrm{mg}$ per day per body weight.

Therefore, our results suggest that all beverages obtained from the two studied yerba mates at all evaluated temperatures may be considered excellent sources of chlorogenic acid intake at concentrations that may have a beneficial biological effect on lipid metabolism, according to the study by Wan and collaborators (Wan et al., 2013). However, it is important to mention that the ingested amount of phenolic compounds does not represent the amount that is bioavailable and that will be biologically active in the body. In this regard, a recent study by Gómez-Juaristi et al. (2018) demonstrated that chlorogenic acids bioavailability (mono and dicaffeoylquinic acids) in humans is low. Thus, further studies are recommended in order to correlate the amounts of chlorogenic acids ingested through mate-based beverages and health-promoting effects.

\section{Conclusions}

The results showed that the increase in water temperature significantly affected the phenolic compounds content in the aqueous extracts prepared with coarse ground yerba mate, with the extracts prepared at $95^{\circ} \mathrm{C}$ showing the highest concentration of all phenolic compounds studied. For the traditional extracts, the difference between temperatures was not statistically significant. In general, irrespective of the water temperature used, the aqueous extracts of chimarrão produced from traditional yerba mate presented a lower content of all the phenolic compounds than the coarse ground (60\% less on average). However, chlorogenic acids content present in traditional and coarse ground extracts of yerba mate, regardless of the temperature used, has significantly higher concentrations than other foods and beverages, evidencing chimarrão as an excellent alternative for the supply of chlorogenic acids.

\section{Acknowledgements}

This study was funded by FAPESP - Foundation for Research Support of the State of São Paulo (process n² 2012/12565).

\section{References}

Bizzotto, C. S., Meinhart, A. D., Rybka, A. C. P., Sobrinho, M. R., Junior, S. B., Ballus, C. A., \& Godoy, H. T. (2012). Quantification of phenolic compounds by capillary zone electrophoresis in extracts of four commercial types of mate herb before and after acid hydrolysis. Food Research International, 48(2), 763-768. http://dx.doi.org/10.1016/j. foodres.2012.06.020.

Boaventura, B. C. B., de Mello Castanho Amboni, R. D., Silva, E. L., Prudencio, E. S., Di Pietro, P. F., Malta, L. G., Polinati, R. M., \& Liu, R. H. (2015). Effect of in vitro digestion of yerba mate (Ilex paraguariensis A. St. Hil.) extract on the cellular antioxidant activity, antiproliferative activity and cytotoxicity toward HepG2 cells. Food Research International, 77, 257-263. http://dx.doi.org/10.1016/j. foodres.2015.05.004.

Colpo, A. C., Rosa, H., Lima, M. E., Pazzini, C. E. F., de Camargo, V. B., Bassante, F. E. M., Puntel, R., Ávila, D. S., Mendez, A., \& Folmer, V. (2016). Yerba mate (Ilex paraguariensis St. Hill.)-based beverages: How successive extraction influences the extract composition and its capacity to chelate iron and scavenge free radicals. Food Chemistry, 209, 185-195. http://dx.doi.org/10.1016/j.foodchem.2016.04.059. PMid:27173551. 
da Silveira, T. F. F., Meinhart, A. D., de Souza, T. C. L., Teixeira Filho, J., \& Godoy, H. T. (2016). Phenolic compounds from yerba mate based beverages - A multivariate optimisation. Food Chemistry, 190, 1159-1167. http://dx.doi.org/10.1016/j.foodchem.2015.06.031. PMid:26213090.

da Silveira, T. F. F., Meinhart, A. D., Souza, T. C. L., Cunha, E. C. E., Moraes, M. R., \& Godoy, H. T. (2017). Chlorogenic acids and flavonoid extraction during the preparation of yerba mate based beverages. Food Research International, 102, 348-354. http://dx.doi. org/10.1016/j.foodres.2017.09.098. PMid:29195958.

De Maria, C. A. B., Trugo, L. C., Miranda, L. S. D. M., \& Salvador, E. (1998). Stability of 5-caffeoylquinic acid under different conditions of heating. Food Research International, 31(6), 475-477. http://dx.doi. org/10.1016/S0963-9969(99)00015-0.

Gebara, K. S., Gasparotto-Junior, A., Santiago, P. G., Cardoso, C. A. L., de Souza, L. M., Morand, C., Costa, T. A., \& Cardozo-Junior, E. L. (2017). Daily intake of chlorogenic acids from consumption of Maté (Ilex paraguariensis A.St.-Hil.) Traditional Beverages. Journal of Agricultural and Food Chemistry, 65(46), 10093-10100. http:// dx.doi.org/10.1021/acs.jafc.7b04093. PMid:29056047.

Gómez-Juaristi, M., Martínez-López, S., Sarria, B., Bravo, L., \& Mateos, R. (2018). Absorption and metabolism of yerba mate phenolic compounds in humans. Food Chemistry, 240, 1028-1038. http:// dx.doi.org/10.1016/j.foodchem.2017.08.003. PMid:28946219.

Heck, C. I., \& De Mejia, E. G. (2007). Yerba mate tea (Ilex paraguariensis): A comprehensive review on chemistry, health implications, and technological considerations. Journal of Food Science, 72(9), R138-R151. http://dx.doi.org/10.1111/j.1750-3841.2007.00535.x. PMid:18034743.

Hong, B. N., Nam, Y. H., Woo, S. H., \& Kang, T. H. (2017). Chlorogenic acid rescues sensorineural auditory function in a diabetic animal model. Neuroscience Letters, 640, 64-69. http://dx.doi.org/10.1016/j. neulet.2017.01.030. PMid:28093303.

Horžić, D., Komes, D., Belščak, A., Ganić, K. K., Iveković, D., \& Karlović, D. (2009). The composition of polyphenols and methylxanthines in teas and herbal infusions. Food Chemistry, 115(2), 441-448. http:// dx.doi.org/10.1016/j.foodchem.2008.12.022.

Isolabella, S., Cogoi, L., López, P., Anesini, C., Ferraro, G., \& Filip, R. (2010). Study of the bioactive compounds variation during yerba mate (Ilex paraguariensis) processing. Food Chemistry, 122(3), 695699. http://dx.doi.org/10.1016/j.foodchem.2010.03.039.

Jeon, J. S., Kim, H. T., Jeong, I. H., Hong, S. R., Oh, M. S., Park, K. H., Shim, J. H., \& Abd El-Aty, A. M. (2017). Determination of chlorogenic acids and caffeine in homemade brewed coffee prepared under various conditions. Journal of Chromatography. B, Analytical Technologies in the Biomedical and Life Sciences, 1064, 115-123. http://dx.doi.org/10.1016/j.jchromb.2017.08.041. PMid:28918319.

Jeszka-Skowron, M., Krawczyk, M., \& Zgoła-Grześkowiak, A. (2015). Determination of antioxidant activity, rutin, quercetin, phenolic acids and trace elements in tea infusions: Influence of citric acid addition on extraction of metals. Journal of Food Composition and Analysis, 40, 70-77. http://dx.doi.org/10.1016/j.jfca.2014.12.015.

Kelebek, H. (2016). LC-DAD-ESI-MS/MS characterization of phenolic constituents in Turkish black tea: Effect of infusion time and temperature. Food Chemistry, 204, 227-238. http://dx.doi. org/10.1016/j.foodchem.2016.02.132. PMid:26988497.

Komes, D., Horžić, D., Belščak, A., Ganić, K. K., \& Vulić, I. (2010). Green tea preparation and its influence on the content of bioactive compounds. Food Research International, 43(1), 167-176. http:// dx.doi.org/10.1016/j.foodres.2009.09.022.
Marques, V., \& Farah, A. (2009). Chlorogenic acids and related compounds in medicinal plants and infusions. Food Chemistry, 113(4), 13701376. http://dx.doi.org/10.1016/j.foodchem.2008.08.086.

Matsunaga, K., Katayama, M., Sakata, K., Kuno, T., Yoshida, K., Yamada, Y., Hirose, Y., Yoshimi, N., \& Mori, H. (2002). Inhibitory Effects of Chlorogenic Acid on Azoxymethane-induced Colon Carcinogenesis in Male F344 Rats. Asian Pacific Journal of Cancer Prevention, 2(2), 163-166. PMid:12718596.

Meinhart, A. D., Bizzotto, C. S., Ballus, C. A., Rybka, A. C. P., Sobrinho, M. R., Cerro-Quintana, R. S., Teixeira-Filho, J., \& Godoy, H. T. (2010). Methylxanthines and phenolics content extracted during the consumption of mate (IIex paraguariensis St. HiI) beverages. Journal of Agricultural and Food Chemistry, 58(4), 2188-2193. http:// dx.doi.org/10.1021/jf903781w. PMid:20058928.

Meinhart, A. D., Caldeirão, L., Damin, F. M., Filho, J. T., \& Godoy, H. T. (2018). Analysis of chlorogenic acids isomers and caffeic acid in 89 herbal infusions (tea). Journal of Food Composition and Analysis, 73, 76-82. http://dx.doi.org/10.1016/j.jfca.2018.08.001.

Miranda, D. D. C., Arçari, D. P., Pedrazzoli, J. Jr, Carvalho, P. D. O., Cerutti, S. M., Bastos, D. H. M., \& Ribeiro, M. L. (2008). Protective effects of mate tea (Ilex paraguariensis) on $\mathrm{H} 2 \mathrm{O}$ 2 -induced DNA damage and DNA repair in mice. Mutagenesis, 23(4), 261-265. http://dx.doi.org/10.1093/mutage/gen011. PMid:18308716.

Peng, B. J., Zhu, Q., Zhong, Y. L., Xu, S. H., \& Wang, Z. (2015). Chlorogenic Acid Maintains Glucose Homeostasis through Modulating the Expression of SGLT-1, GLUT-2, and PLG in Different Intestinal Segments of Sprague-Dawley Rats Fed a High-Fat Diet. Biomedical and Environmental Sciences : BES, 28(12), 894-903. http://dx.doi. org/10.3967/bes2015.123. PMid:26777909.

Pérez-Burillo, S., Giménez, R., Rufián-Henares, J. A., \& Pastoriza, S. (2018). Effect of brewing time and temperature on antioxidant capacity and phenols of white tea: Relationship with sensory properties. Food Chemistry, 248, 111-118. http://dx.doi.org/10.1016/j. foodchem.2017.12.056. PMid:29329833.

Pimentel, G. D., Lira, F. S., Rosa, J. C., Caris, A. V., Pinheiro, F., Ribeiro, E. B., do Nascimento, C. M. O., \& Oyama, L. M. (2013). Yerba mate extract (Ilex paraguariensis) attenuates both central and peripheral inflammatory effects of diet-induced obesity in rats. The Journal of Nutritional Biochemistry, 24(5), 809-818. http://dx.doi.org/10.1016/j. jnutbio.2012.04.016. PMid:22841395.

Shao, P., Zhang, J. F., Chen, X. X., \& Sun, P. L. (2015). Microwaveassisted extraction and purification of chlorogenic acid from by-products of Eucommia Ulmoides Oliver and its potential anti-tumor activity. Journal of Food Science and Technology, 52(8), 4925-4934. http://dx.doi.org/10.1007/s13197-014-1571-8. PMid:26243912.

Shi, H., Shi, A., Dong, L., Lu, X., Wang, Y., Zhao, J., Dai, F., \& Guo, X. (2016). Chlorogenic acid protects against liver fibrosis in vivo and in vitro through inhibition of oxidative stress. Clinical Nutrition, 35(6), 1-8. http://dx.doi.org/10.1016/j.clnu.2016.03.002. PMid:27017478.

Siswanto, F. M., Oguro, A., \& Imaoka, S. (2017). Chlorogenic acid modulates hypoxia response of Hep3B cells. Personalized Medicine Universe, 6, 12-16. http://dx.doi.org/10.1016/j. pmu.2017.03.001.

Thompson, M., Ellison, S. L. R. \& Wood, R. (2002). Harmonized guidelines for single-laboratory validation of methods of analysis. Pure and Applied Chemistry, 74(5), 835-855. http://dx.doi.org/10.1351/ pac200274050835. 
Wan, C. W., Wong, C. N. Y., Pin, W. K., Wong, M. H. Y., Kwok, C. Y., Chan, R. Y. K., Yu, P. H. F., \& Chan, S. W. (2013). Chlorogenic acid exhibits cholesterol lowering and fatty liver attenuating properties by up-regulating the gene expression of PPAR- $\alpha$ in hypercholesterolemic rats induced with a high-cholesterol diet. Phytotherapy Research, 27(4), 545-551. http://dx.doi.org/10.1002/ ptr.4751. PMid:22674675.

Wan, W., Liu, Z., Qu, X., Chen, M., \& Gao, H. (2012). Aqueous Extract of Yerba Mate Tea Lowers Atherosclerotic Risk Factors in a Rat Hyperlipidemia Model. Phytotherapy Research, 27(8), 1225-1231. http://dx.doi.org/10.1002/ptr.4856. PMid:23055269.

Wang, G. F., Shi, L. P., Ren, Y. D., Liu, Q. F., Liu, H. F., Zhang, R. J., Li, Z., Zhu, F. H., He, P. L., Tang, W., Tao, P. Z., Li, C., Zhao, W. M., \& Zuo, J. P. (2009). Anti-hepatitis B virus activity of chlorogenic acid, quinic acid and caffeic acid in vivo and in vitro. Antiviral Research,
83(2), 186-190. http://dx.doi.org/10.1016/j.antiviral.2009.05.002. PMid:19463857.

Wang, Z., Clifford, M. N., \& Sharp, P. (2008). Analysis of chlorogenic acids in beverages prepared from Chinese health foods and investigation, in vitro, of effects on glucose absorption in cultured Caco- 2 cells. Food Chemistry, 108(1), 369-373. http://dx.doi.org/10.1016/j. foodchem.2007.10.083.

Wu, D., Bao, C., Li, L., Fu, M., Wang, D., Xie, J., \& Gong, X. (2015). Chlorogenic acid protects against cholestatic liver injury in rats. Journal of Pharmacological Sciences, 129(3), 177-182. http://dx.doi. org/10.1016/j.jphs.2015.10.005. PMid:26598002.

Yan, Y., Liu, N., Hou, N., Dong, L., \& Li, J. (2017). Chlorogenic acid inhibits hepatocellular carcinoma in vitro and in vivo. The Journal of Nutritional Biochemistry, 46, 68-73. http://dx.doi.org/10.1016/j. jnutbio.2017.04.007. PMid:28458139. 